УдК: 93/94

\title{
Е.А. Крестьянников
}

\section{«СВОБОДНАЯ ПРОФЕССИЯ» П.В. ВОЛОГОДСКОГО: АДВОКАТСКИЕ ТРАЕКТОРИИ ТОМСКОГО ЮРИСТА}

\begin{abstract}
Рассмотрены участие Петра Васильевича Вологодского в судебных процессах в качестве защитника и обвинителя, а также его вклад в становление организации сословия поверенных; определяется круг интересов и приоритетов сибирского правоведа-практика в адвокатской и правозащитной деятельности. Показано, что будущий премьер-министр правительств Белой России относился к выбранной специальности ответственно и являлся адвокатом высокого уровня, отстаивал автономию присяжной адвокатуры и был активно задействован в ее самоуправлении.

Ключевые слова: П.В. Вологодский; Сибирь; адвокатура; судебные процессы.
\end{abstract}

Либерализм эпохи Александра II наполнил сферу юстиции началами бессословности, состязательности, устности, гласности процесса, независимости суда и несменяемости судей, права подсудимого на защиту. Тем самым судебная реформа 1864 г. заложила базу для развития правового государства и гражданского общества, в основе которых лежит принцип законности. В обеспечении последней непременно одну из ведущих ролей играют защитники права - адвокаты. В пореформенной России адвокатура, несмотря на быстро сформировавшееся неприятие самодержавием, переживая в свой адрес нападки и испытывая ограничения, деформируясь сама и иногда теряя ориентиры для своего совершенствования, все-таки сумела создать особенную и автономную от политического режима среду. Сословие и / или корпорация - те ключевые понятия, какими в Российской империи обозначали себя присяжные поверенные. Корпоративная организация предполагает отсутствие в той или иной мере внешнего влияния на собственное функционирование, делает ставку на моральную ответственность участников, формирует особенную культуру - модели поведения внутри и за пределами содружеств, разделяемые их членами; она немыслима без лидеров, в нашем случае тех, кто завоевал себе безупречную репутацию и уважение в глазах коллег и общества благодаря своей самодостаточности и высокому профессионализму, реализуемым в судебной и правозащитной деятельности.

Когда в конце XIX в. независимая адвокатура стала создаваться в Сибири, в ее лагере с бременем лидерства сразу оказался П.В. Вологодский, любивший называть свое ремесло «свободной профессией». Об его адвокатской практике вроде бы общеизвестно, однако в исторической литературе она получила фрагментарное отражение, и из работ, в которых говорится об участии Петра Васильевича в отдельных процессах (из последних трудов стоит выделить диссертацию Е.А. Казаковой [1] и монографию М.В. Шиловского [2]), цельного представления о ней читатель не составит. Между тем следов участия выдающегося сибиряка в судебных состязаниях и в организации сословия поверенных сохранилось немало. Изучение, прежде всего, периодической печати ${ }^{1}$, отчетной документации негосударственных организаций и материалов делопроизводства, с применением компаративистских методик и микроанализа позволяет реконструировать пути и атмосферу развития профессио- нальной карьеры томского юриста, выяснить его отношение к своей работе, оценить вклад в общественную эмансипацию, а также копилку адвокатских корпоративности, морали и мастерства.

Прочным основанием общественной ${ }^{2}$ и политической активности ${ }^{3}$ будущего премьер-министра являлись его успешные занятия адвокатурой ${ }^{4}$, начало которым было положено еще до введения в 1897 г. Судебных уставов Александра II в Сибири [13. С. 116]. Он участвовал во многих интересных процессах, ставших резонансными благодаря освещению в прессе. Например, защищал потомственного дворянина, старшего чиновника особых поручений при томском губернаторе П.Ф. Девьена, обвинявшегося в оскорблении полицейского пристава, князя А.С. Оболенского [14], ответственного редактора кратковременно выходившего «Вестника Сибири» И.П. Баева [15], являлся защитником по делу о краже судебных дел из камеры мирового судьи и составлении нескольких подложных ассигновок от имени того же судьи (процесс «привлек многочисленную публику») [16]. Любопытство читающей публики могли вызвать заседания, в которых Петр Васильевич выступал обвинителем. Ярким и даже заслужившим отчета в столичной газете «Право» было дело по обвинению учительницей Греховой в клевете протоиерея И. Беневоленского, осужденного по окончании слушаний [17]. 26 марта 1901 г. в Томском окружном суде рассматривалось сразу четыре дела против редактора «Сибирского вестника» Г.В. Прейсмана «в оклеветании в печати». По двум из них обвинял П.В. Вологодский, и по судебному приговору шеф популярной томской газеты приговаривался к аресту на месяц $[18,19]$. Состав клиентуры также свидетельствовал о спросе на услуги адвоката: он являлся поверенным известных в Томске предприятий «Семен Кузьмин и сыновья», «А.Ф. Второв и сыновья», «Евграф Кухтерин и сыновья» [1. С. 61], предъявлял иски от Екатеринбургского отделения Волжско-Камского банка и Екатеринбургского общественного банка [20].

Его таланты как адвоката и защитника народных прав еще больше раскрылись в условиях напряжения Первой русской революции. Поверенному, «пользовавшемуся общественными симпатиями и общественным доверием», в значительных политических процессах сопутствовала удача: ни один из его подзащитных не был приговорен к смертной казни, «ему всегда удавалось смягчить судей» [21]. Известно, в 
частности, что 26 августа 1905 г. на выездной сессии Омской судебной палаты в Томске был оправдан защищаемый им телеграфист ст. Тайга Л.Ф. Бизюкин, обвинявшийся в распространении прокламаций Томского комитета РСДРП [22. С. 144]. На исходе революции Петр Васильевич защищал трех подсудимых (других троих - В.Н. Анучин, М.Р. Бейлин и М.И. Преловский) в нашумевшем деле о социалдемократическом сообществе, проходившем не гденибудь, а в военном суде - более строгом, чем общие судебные места. По сообщению корреспондента «Красноярца», поверенным тогда удалось «разрушить в судебном заседании этот громкий процесс, в котором даже военный суд не нашел ничего серьезного» [23]. Вообще, как пишет Е.А. Казакова, П.В. Вологодский «принимал участие, пожалуй, в самых громких политических процессах в Сибири того периода - в процессе томских демонстрантов 1905 г., в деле об экспроприации на томской ветке Сибирской железной дороги, в процессе по делу председателя Совета депутатов рабочих красноярских железнодорожных мастерских...» [1. С. 63].

Находясь в эпицентре событий и являясь в полном смысле слова правозаступником, присяжный поверенный оставил заметный след в анналах знаменитого октябрьского погрома 1905 г. в Томске. 18 октября казаки с применением силы разгоняли томскую молодежь на площади вблизи здания окружного суда, оттуда выбежал он и «обратился к казачьему офицеру, командовавшему этой полусотней казаков, с просьбой прекратить дальнейшее бессмысленное избиение детей, на него напали два казака и начали бить нагайками. Казаки рассекли Вологодскому лицо и сильно его избили» [24. С. 10]. Сам адвокат описывал этот символизировавший драматизм момента эпизод следующим образом: «18 октября учащиеся снова пошли “снимать занятия” в средних учебных заведениях и, когда они на Соляной площади пред зданием коммерческого училища вели переговоры с директором этого училища по поводу их требования о прекращении занятий в этом учебном заведении, на них под непосредственным распоряжением и руководством местного полицмейстера Никольского налетел отряд казаков и с помощью вооруженных солдат и полицейских произвел такое жестокое избиение учащихся и некоторых лиц из публики, пробовавших заступиться за учащихся (особенно пострадал гласный думы и председатель училищной комиссии П.В. Вологодский), что мужчины плакали, а женщины впадали в истерику только при одних рассказах об этой дикой расправе» [25. С. 252].

Дело о томском погроме имело для Петра Васильевича профессиональное продолжение: в августе 1909 г. в Томском окружном суде проходил судебный процесс, широко освещавшийся ведущей местной прессой ${ }^{5}$, в котором подсудимыми являлись 85 человек, а он выступал адвокатом со стороны потерпевших и гражданских истцов. Особенный эффект разбирательству придавало то, что с 20 августа общим защитником для всех обвиняемых стал один из самых знаменитых присяжных поверенных империи, известный националист, член головного совета правого Союза русского народа П.Ф. Булацель, в своих взглядах резко контрастировавший с остальной русской адвокатурой ${ }^{6}$. Процесс, имевший шанс превратиться в площадку для состязания адвокатских школ, с подачи властей, не желавших накалять обстановку, однако, обернулся мероприятием, в ходе которого председатель суда М.А. ПодгоричаниПетрович старался не доводить расследование до выяснения глубинных причин кровавого конфликта (в томском погроме погибло более полусотни томичей). В частности, он пресек попытку П.В. Вологодского выяснить у одного из свидетелей «не было ли ужасное событие 1905 г. результатом попустительства властей» [2. С. 106-110].

Поведение П.Ф. Булацеля также не способствовало честной адвокатской борьбе. Далеко за пределами Томска стали известны его приемы, какие он использовал в заседаниях по тому делу. Так, в начале слушаний 22 августа столичный поверенный, вероятно стремясь накалить страсти и вывести из терпения противоборствующую сторону, зная, что один из защитников - выдающийся сибирский адвокат М.Р. Бейлин ${ }^{7}$ - еврей, целенаправленно разжигал антисемитскую тематику и использовал соответствующую риторику. Председательствующий отказал ему в вызове дополнительных свидетелей, но тогда мастер провокации продолжал требовать все-таки это сделать, поскольку, по его мнению, вызываемые свидетели «были очевидцами того, как сын того жида, который вчера распространялся о том, что погром его разорил, - убил православного рабочего». М.А. Подгоричани-Петрович попросил не применять оскорбительных выражений. На это приезжий поверенный разразился объяснениями, мол, понятие «жид» общеупотребительно и используется в законодательстве. Председателю пришлось еще раз высказать предостережение и услышать в ответ: «Если в Томске ... принято называть жидов евреями, я подчиняюсь. Но ... я лично с тех пор, как у меня был в Петербурге один крупный литературный процесс, когда мне пришлось убедиться, что вся “прогрессивная" печать находится в руках жидов, всех евреев называю жидами, а так называемую “прогрессивную” печать - жидовской» [28].

Вместе с тем судьба тесно связала П.В. Вологодского с судом присяжных. В ходе судебной реформы конца XIX в. Сибирь не получила это учреждение. Ему не было места в регионе, по мнению чиновников, разрабатывавших преобразование, из-за «малой населенности края», многочисленности «неблагонадежного ссыльного элемента», а также «инородцев, не знающих русского языка и стоящих на низкой ступени умственного развития» [29. Л. 14 об.]; препятствием служили «воззрения» сибиряков «относительно значения и важности некоторых преступлений»; затруднения вызывало якобы отсутствие «более или менее развитого класса благонадежных людей» [30. Л. 52, 129 об.]. Однако сибирская общественность не отчаивалась, на что имелись основания ${ }^{8}$, и, например, профессор Томского университета Н.Н. Розин подбадривал местную публику мыслями о введении «суда общественной совести» в грядущем: «Будем же питать твердую надежду, что русский народ никогда не уга- 
сит этого маяка; будем верить, что свет его скоро падет и в нашу далекую Сибирь» [32. С. 35]!

Ожидавшийся десятилетиями и потому еще более счастливый для сибиряков акт (институт присяжных заседателей вводился в Тобольской и Томской губерниях на основании закона от 10 мая 1909 г. [33; 34. № 31862]) получил высочайшую оценку местной общественности: «вся сибирская пресса единодушно приветствовала это крупное общественное событие» [35], мероприятие местные жители называли даже «великой реформой» и выражали по его поводу самые пылкие верноподданнические чувства [36. Л. 1-32]. П.В. Вологодский также всецело приветствовал долгожданное нововведение, поскольку считал институт присяжных заседателей «лучшей формой для рассмотрения уголовных преступлений» [37]. Ему давалась возможность пролить на родной край частицу того «света», о каком говорил Н.Н. Розин. Он мог поучаствовать в отправлении правосудия «по-новому» членом коллегии присяжных (его имя включалось в первоначальные списки) [38. С. 333], но представилась еще большая удача защищать подсудимого в первом же сибирском процессе «суда общественной совести». Вместе с М.Р. Бейлиным он выступил защитником по делу Е.П. Карепиной, убившей своего мужа. Выяснилось, что последний в состоянии алкогольного опьянения регулярно избивал жену, в ночь убийства - также малолетних детей, и мужеубийца, как заключила врачебная экспертиза, в состоянии из «разряда патологических аффектов» несколькими ударами топором по голове лишила его жизни. Женщина сознавалась в убийстве, а речи защитников заставили ее рыдать. Присяжными заседателями был вынесен сильно раздражавший российских противников суда присяжных и вызывавший восторг изголодавшихся по свободам сибиряков вердикт - «нет, не виновна», встреченный присутствовавшей публикой аплодисментами [39]. Тут в одночасье разрушился миф о невежестве сибирского населения и «ненормальностях» его мировосприятия. Тот самый первый в Сибири состав заседателей от народа выступил с инициативой снабдить оправданную средствами на жизнь [40], т.е. проявил такие человеколюбие и сострадание, на какие только способны самые нравственные члены общества.

Взгляды Петра Васильевича на адвокатское ремесло, представления о высококлассном поверенном и рефлексия по поводу своего труда реконструируются на основе его речей и текстов. В 1904 г. он опубликовал в «Сибирском вестнике» «Письма с дороги», где содержались переживания и мысли о собственной работе, которые, пожалуй, не требуют комментариев и заслуживают, чтобы их привести полностью: «Но вот я “бросил службу” и посвятил себя “свободной профессии”. И когда после двух лет жизни “свободной профессии”, исполненных, весьма естественно в первое время, разочарований, опасений, надежд, а главное, нервозности, я решил поехать в столицу, чтобы “отдохнуть и освежиться”, - я, человек свободной профессии, почувствовал всю связанность свою свободной профессией. Не подумайте, что с течением времени моя семейная обстановка стеснила меня в этом отношении материально или нравственно. Нет, с переходом в свободную профессию, мне в семейном отношении открывался еще больший простор, чтобы оставить “кров родимый, дом любимый”. Но я не мог вырваться из своего города, потому что меня задерживали дела. Когда приходится брать на свою обязанность дело, по добровольному соглашению с лицом, к тебе обращаются за этим делом, ты уже связан кровными узами с судьбой этого дела, ты живешь его жизнью, всякие пертурбации его волнуют и тебя, ты уже не можешь с легкостью сердца, без сомнения и тревоги за судьбу этого дела передать его своему заместителю, а часто и лицо, передавшее тебе свое дело, требует, чтобы дело было проведено под непосредственными твоими наблюдением и руководством, а между тем ты не свободен его направлять именно в этот день, неделю, месяц. Ты зависишь от других лиц, от учреждений, в руках которых находится судьба твоего дела. Все это заставляет откладывать поездку день-за-день и, в конце концов, приходится задуманную поездку для данного сезона признать несостоявшейся» [41].

В речи на заседании Томского юридического общества 26 апреля 1903 г., посвященной В.Д. Спасовичу - «патриарху», «цвету» и «королю» русской адвокатуры, «по праву считавшемуся самым заслуженным присяжным поверенным» [42. С. 26, 340; 43. С. 488], Петр Васильевич на образчике последнего определенно обозначил, каким надлежало быть хорошему защитнику в суде, какими дарованиями, навыками и техникой долженствовало обладать, чтобы добиться успеха. П.В. Вологодский тогда рассказывал, как сначала Владимир Данилович, словно завлекая всех присутствовавших, присяжных заседателей и коронных судей в свою хитроумно продуманную игру, выглядел неубедительно («В.Д. не обладает внешней ораторской наружностью. Так что, когда поднимается со скамьи защиты нескладная, неуклюжая фигура В.Д., когда он, заикаясь и переваливаясь, начинает свою речь, в зале среди публики, ожидавшей увидеть иную фигуру и услышать иной язык, раздается шепот недоумения. Первые фразы его речи неприятно поражают слух. Кажется, что слово не дается оратору, что оно является на свет в потугах и муках борьбы»), и вдруг наступало резкое перерождение: «Но проходит несколько минут и перед слушателями развертывается дивная художественная поэма, богатая яркими красками, оригинальными картинами, неожиданными сравнениями, поражающая остроумием и силой обобщающего анализа. Слово его отчеканивается и с силой врезывается в память, огромный голос звучит твердо и уверенно. Живая энергичная речь В.Д. одинаково сильная в синтезе, никогда не упускающая из виду подсудимого, как брата по человечеству, проникнутая разумным отношением к увлечениям молодого возраста, всегда производила впечатление на присяжных и привлекала особое к себе внимание суда. Если вдумчивость в дело, изучение его во всех мельчайших подробностях, отсутствие напускного пафоса и простота речи, в связи с глубиною и богатством ее содержания, должны служить образцом и примером для лиц, посвящающих себя адвокатуре, то 
такой образец дал в самых широких размерах своею судебной деятельностью В.Д. Спасович» [44].

Судя по признанию, какое заслужил будущий премьер-министр участвуя в судебных процессах, наукой и искусством защиты он владел прекрасно, а будучи активным членом общества, в качестве адвокатского инструментария использовал указания на противоречия тогдашней действительности. Так и случилось по делу протоиерея И. Беневоленского. Само начало обвинительной речи указывало на стремление оратора защищать угнетаемых и склонять на их сторону чинов юстиции: «Гг. судьи! Дело, которое предстоит вашему рассмотрению, является редким в летописях судебных. Редким, прежде всего, по личности подсудимого и потерпевшей. Борцами за честь и достоинства свои выступают силы неравные. С одной стороны, учительница приходского училища маленького уездного городка Сибири, с другой, властный протоиерей местного собора и благочинный местных церквей...». Далее обвинитель подчеркивал разницу, которая имелась в социальном статусе подсудимого и потерпевшей, и специально остановился на теме высокого общественного значения этого дела [17].

П.В. Вологодский на процессе о томском погроме, в отличие от П.Ф. Булацеля, не был замечен в употреблении нечестных способов. Как следует из речей присяжного поверенного, его не ограничивали сиюминутные и отдельные профессиональные успехи; он мыслил шире и проявлял себя склонным к детальному анализу обстановки и обобщениям, в тот момент оформлявшимся в яркие политические заявления. На завершающих заседаниях ему пришлось констатировать, что Россия коренным образом изменилась и уже никогда не будет прежней: «Широкая волна новой жизни нахлынула неожиданно на темный и невежественный народ, и безотчетный страх перед новыми явлениями жизни овладел, как всегда в этих случаях, этим людом, а те, кто понимали, что их, старых властителей жизни...». «Оставьте властителей жизни, г. Вологодский, и ближе к делу», - здесь в духе всего разбирательства была прервана речь председателем суда [45].

Несомненно, политические убеждения поверенных накладывали серьезный отпечаток на их профессиональную деятельность в суде, но имелась та область сфера самоуправления, в какой адвокаты всячески стремились культивировать аполитизм. Например, еще в отчете санкт-петербургского совета присяжных поверенных за 1882/1883 гг., т.е. сразу после известного антиправительственного взрыва, фиксировалась такая мысль: «В корпорации присяжных поверенных одновременно и совместно могут действовать люди самых различных и даже противоположных политических убеждений; они одинаково будут служить честью и украшением корпорации, если только добросовестно, с умом и талантом будут исполнять свои адвокатские обязанности» [46. С. 9]. В начале XX в. адвокатура бросилась решать новые политические задачи и над ее сплоченностью нависла опасность вплоть до общего разложения всего сословия [26. C. 328-348]; тогда было особенно важно сохранить хладнокровие тем, кто определял его развитие. К по- следним в Сибири безусловно относился П.В. Вологодский, много сделавший для присяжных поверенных края и управлявший ими через участие в организации и работе омского совета, открывшегося в 1911 г. [47]. Политик, он тем не менее не совершал разрушительных для корпорации действий, а некоторые резолюции руководства западносибирской адвокатуры могут служить подтверждением того, что и не желал вносить никакого политического раскола в адвокатскую среду. Показательно решение вопроса, поставленного перед омским советом одним из помощников присяжного поверенного о своей партийной принадлежности. Совет занял явно аполитичную позицию (доклад по этому делу готовил М.Р. Бейлин), не посчитав нужным обсуждать такие вещи: «Партийные воззрения того или иного члена сословия дело совершенно личное и не могут дать оснований к каким бы то ни было постановлениям совета» [48. C. 111]. Может благодаря терпимости, не в последнюю очередь формируемой Петром Васильевичем в качестве вожака западносибирской адвокатуры, в крае не замечалось серьезных раздоров, таких как между знаменитыми восточносибирскими адвокатами М.С. Стравинским ${ }^{9}$ и Г.Б. Патушинским ${ }^{10}$, «личное столкновение» которых влияло даже на формирование состава совета присяжных округа Иркутской судебной палаты [52].

Будущий премьер-министр был причастен к созидательной и направленной на пользу собственного сословия деятельности. Хотя он может быть охладевал к совету [47. С. 155], но, за отсутствием пока других организационных форм совершенствования адвокатуры, не покидал его и держал в голове идею о несомненной полезности заведения, прекрасно усвоив те смыслы о великом призвании этого учреждения, о каком когда-то рассуждал выдающийся российский общественный деятель и адвокат К.К. Арсеньев: «Обычаи и предания образуются только в среде корпорации, а корпорация немыслима без самоуправления, без органа, который бы служил ее представителем. Присяжных поверенных мы видим везде, где введены в действие новые судебные уставы; но сословие присяжных поверенных является только там, где открыт совет присяжных поверенных» [53. С. 3].

Вероятно, П.В. Вологодский вполне разделял взгляды на нужность корпоративных назиданий и наказаний в интересах улучшения сословия, практиковавшихся адвокатскими самоуправляющимися учреждениями $^{11}$, иначе не объяснить его активного, правда, с постепенным угасанием, участия в работе омского совета, о чем свидетельствовали отчеты последнего. В заседаниях проделывалась работа по рассмотрению дисциплинарных производств, родственная по духу и технологии участию в судебных процессах - приходилось внимательно изучать дело, обвинять и защищать, делая доклад перед жюри заведения, и даже осуществлять настоящие следственные действия. Во второй год деятельности совета (отчет за первый год не публиковал фамилии фигурантов дисциплинарных расследований) Петр Васильевич являлся докладчиком по десятку дел такого рода из примерно сотни, что даже превышало среднюю 
нагрузку (разумеется, если особняком поставить председателя совета омича И.А. Поваренных, который, при наличии семи членов, разобрал почти около половины всех дел) [48. С. 11-121]. На третий год будущий премьер-министр сделал семь докладов, а на четвертый - всего один, причем его имя упоминалось все реже и реже в числе заседавших [54. С. 17-100; 55. С. 16-131].

Не без участия П.В. Вологодского лица «свободной профессии» округа Омской судебной палаты выносили вызывающе независимые решения, вступавшие в противоречие с навязанными самодержавием правилами игры. Так, была подхвачена инициатива советов присяжных поверенных других регионов, вопреки существовавшим нормам вслед за европейскими адвокатами ставших принимать в свои ряды женщин $[56,57]$. В Омске также зачислили в число помощников присяжных поверенных окончившую юридический факультет Московского университета Л.П. Рушковскую, и она сделалась первым в Сибири адвокатом женского пола, что с восторгом встретила провинциальная пресса $[58,59]$. Но прокурор местной судебной палаты В.В. Едличко ${ }^{12}$ потребовал отменить данное постановление [61. Л. 38-50], и девушка была исключена из сословия [62. С. 3]. Тот же вредоносный для адвокатуры чиновник сделал все, чтобы препятствовать омскому совету в открытии томской и омской комиссий помощников присяжных поверенных (ими адвокаты-стажеры пытались компенсировать отсутствие собственной корпоративности и независимости). В конце концов, эти организации, только начавшие существование, 10 февраля 1912 г. были ликвидированы росчерком пера ретивого прокурорского работника [62. С. 3-4; 63. Л. 12-12 об., 17, 19].

Стремление к единению лиц «свободной профессии» вызывалось энергетическими потоками, которыми питались поверенные от общества, желавшего эмансипации, избавления от предрассудков, пережитков и неравенства. Адвокатская практика была одним из тех немногих каналов, через который подданным доставлялось понимание справедливости, и такие, как П.В. Вологодский, воспринимались ее прямыми носителями. В результате реноме присяжного поверенного в родном крае достигло настолько высокой степени безукоризненности, что когда революционная волна смывала остатки царского режима, сообщество правоведов-практиков региона единодушно выдвинуло его на пост старшего председателя Омской судебной палаты, а он, не без колебаний, согласился на предложенную должность [21, 64]. Августовские 1917 г. проводы Петра Васильевича на новую службу стали значимым событием томской жизни, лишний раз свидетельствуя, насколько важную роль играл этот сибиряк в местных общественных отношениях. Богатый профессиональный опыт удачливого адвоката, идейность, способность сплотить вокруг себя специалистов, «отбросить формальное отношение к делу» (последняя характеристика принадлежала ректору Томского университета В.В. Сапожникову) [65] и преодолеть границы узкопрофессиональных интересов, апробированные на адвокатском поприще, неуклонное следование принципам судейского единства ${ }^{13}$ сделали его персону понятной для окружающих и весьма авторитетной, сформировали доверительное к нему отношение, обеспечив возможность политического взлета в то время, когда убеждения и нравы многих не отличались устойчивостью.

Глубинный смысл гласного и состязательного судопроизводства - выражение общественного мнения и выработка отношений, характерных для гражданского общества. Следовательно, адвокат во всех своих ипостасях оказывает давление на государство, указывая ему на уравновешенный с социальными потребностями сценарий развития. Но то, не будучи правовым, каким и являлась Российская империя, видело опасность в адвокатуре, которая непременным условием своего существования выбирала автономию и оформлялась в «свободную профессию», саморегулируемую и сплачиваемую на основе сильнейшей корпоративности, определяющей и уровень жизнеспособности всего сословия, и степень успешности отдельного поверенного в частном судебном заседании. Таким образом, П.В. Вологодский - высококлассный юрист и великолепный адвокат - через энергичную адвокатскую практику и активное участие в сословном самоуправлении, посредством реализации себя в любимом ремесле, дающем свободу, своей деятельностью, без сомнения, содействовал избавлению социума от излишеств государственного принуждения.

\section{ПРИМЕЧАНИЯ}

1 Периодика составляет не только наиболее весомый источник по теме статьи, но и требующий специального источниковедческого анализа. С одной стороны, газеты уже отобрали для потомков наиболее громкие судебные процессы, изобразили их участников, что, безусловно, удобно историку. С другой стороны, сама специфика адвокатской деятельности, требующей рекламировать собственные успехи (в случае с П.В. Вологодским таких возможностей было предостаточно, поскольку тот имел теснейшую связь с томской прессой как публицист и товарищ редакторов с издателями), заставляет крайне критически относиться к газетной информации. В указанном смысле примером злоупотребления саморекламой являлся частный поверенный А.А. Жалудский, которого прямо обвиняли в том, что он в своем же «Красноярском вестнике», публикуя многочисленные отчеты о выигранных делах, «расписывал себя во всех цветах радуги» [3].

2 Деятельность Петра Васильевича на благо общества была настолько широка и многогранна, что невольно приходится задумываться над вопросом о неисчерпаемости его человеческих сил. Так, за короткий промежуток времени он замечался в качестве члена комиссии Томского общества земледельческих колоний и ремесленных приютов, занимавшейся осмотром построенных для колоний зданий [4], главы комитета по строительству в Томске «гоголевского» дома [5], и даже руководителя труда об истории Томска [6].

3 Чрезвычайную политическую энергичность П.В. Вологодский проявил в годы Первой русской революции. Например, 28-29 августа 1905 г. съезд Сибирского областного союза состоялся именно на его томской квартире, за которой тогда внимательно наблюдала политическая полиция [7. С. 125; 8. С. 163]. Вообще, томские жандармы называли дом Петра Васильевича штабом революционеров [9. C. 20]. Тогда поверенный являлся эсером, партийность после революции определить сложнее. Сам Петр Васильевич не давал на этот вопрос определенных ответов: «Но я никогда не был демагогом, никогда не был узко партийным человеком, не способным подавлять в себе чувства личного огорчения и неприятностей ради общих интересов» [10]. Между тем советская «История Сибири» называла присяжного 
поверенного кадетом-«прогрессистом» [11. С. 96]. В конце концов, «историки до сих пор не могут договориться о его партийной принадлежности. Одни зачисляют его в эсеры, другие считают кадетом, самые “проницательные” квалифицируют как полуэсераполукадета» [12. С. 2].

4 Е.А. Казакова заверяет, что П.В. Вологодский выигрывал большинство уголовных дел [1. С. 61]. Безусловно, он был удачливым адвокатом, но вряд ли состояние источниковой базы позволяет современному исследователю провести необходимый для подобных утверждений подсчет.

5 Так, самая тиражная за Уралом газета томская «Сибирская жизнь» в своих десяти выпусках подряд, с 18 по 28 августа 1909 г., рассказывала читателям о ходе процесса.

${ }^{6}$ В ноябре 1904 г. на собраниях, посвященных сорокалетию Судебных уставов Александра II, российская адвокатура в единодушном порыве выступила за принятие резолюции о необходимости коренного изменения государственного строя. Единственный громкий голос против начинания прозвучал именно от П.Ф. Булацеля, который «категорически опровергал, будто бы при современном режиме вообще немыслимо никакое духовное преуспеяние народа и невозможно даже правильное отправление правосудия» [26. С. 328-329].

${ }^{7}$ Он был широко известен в Сибири. Например, «Красноярец» его характеризовал как «одного из талантливейших томских адвокатов» [27].

${ }^{8}$ На заседании Государственного совета по поводу судебной реформы в Сибири 6 апреля 1896 г. указывалось: «Развитие сибирского края, за последние годы, идет вперед быстрыми шагами. Поэтому, быть может, в недалеком будущем наступит пора, когда представится возможным устроить суд присяжных, если не в большей части Сибири, то хотя бы в западных ее губерниях. Эти последние и ныне в культурном отношении далеко ушли вперед по сравнению с остальными областями сибирской окраины и потому не могут быть с ними сравниваемы и подводимы под один общий уровень. С наступлением для означенных местностей благоприятного времени к восприятию указанной формы суда, Министерство юстиции, надобно надеяться, не преминет сообразить этот вопрос и даст ему надлежащее направление» [31. Л. 190 об.].

${ }^{9}$ М.С. Стравинский - старейшина адвокатского цеха региона. Как и П.В. Вологодский, вместе с сибирскими присяжными поверенными прошел путь от начала до конца, в годы Гражданской войны также заняв важные посты в государственном аппарате антибольшевистского режима. Осенью 1918 г. был назначен членом Сибирского Высшего суда, затем членом Гражданского департамента Правительствующего Сената [49; 50].

${ }^{10}$ Судьбы П.В. Вологодского и Г.Б. Патушинского переплелись теснейшим образом, когда в июле 1918 г. первый стал председателем Совета министров и министром иностранных дел, а второй - министром юстиции Временного Сибирского правительства [51. Л. 19].

${ }^{11}$ На этот счет в предисловии к своеобразному кодексу чести сословия - «Правилах адвокатской профессии в России», изданному в 1913 г. и вобравшему в себя из отчетов советов всевозможные мудрости за годы их существования в стране, - говорилось: «Адвокат, будучи независим, тем не менее должен в каждый момент своей деятельности сознавать, что он не отдельная частица какой-то огромной “совокупности”, имеющий общее с другими адвокатами только однородность заработка, но что он член целого “сословия”, целой “корпорации”, объединяющей всех ее членов, направляющей их и в то же время охраняющей их честь и достоинство. Адвокат в своей деятельности всегда должен помнить, что за ним стоят не отдельные единицы собратьев по профессии, до которых ему может и не быть никакого дела, а стоит целое сословие, как нечто единое, мощное, достоинство которого он должен оберегать; сословия, которое в лице избранных самими адвокатами советов располагает достаточной силой заставить каждого из своих членов руководиться в своей деятельности и поведении не личными только мотивами своего благополучия и соображениями достоинства и чести целого сословия и установленными ими правилами и традициями» [46. С. VII].

12 Вообще, этот судебный деятель замечался в недоброжелательности к адвокатуре, которая проявилась, в частности, в одном из приездов в Томск. Местные поверенные пришли к нему с приветствием чуть ли не в полном составе (среди них вполне мог быть и П.В. Вологодский), но их ожидал настолько «холодный» прием, что «адвокаты были крайне смущены» и «даже сетовали, что задумали это злополучное представление» [60].

${ }^{13}$ Уезжая служить в Омск, Петр Васильевич обратился к сотрудникам юстиции Томска: «Я всегда был сторонником солидарности отношений судебной магистратуры, прокуратуры и адвокатуры. Все мы должны служить одному великому делу - делу правосудия» [64].

\section{ЛИТЕРАТУРА}

1. Казакова Е.А. П.В. Вологодский: личность и общественно-политическая деятельность (1863-1920 гг.) : дис. ... канд. ист. наук. Томск, 2008. $363 \mathrm{c}$.

2. Шиловский М.В. Томский погром 20-22 октября 1905 г. : хроника, комментарий, интерпретация. Томск : Изд-во Том. ун-та, 2010.150 с.

3. Хроника // Сусанин. 1911. 2 марта.

4. Корреспонденция «Енисея» // Енисей. 1901. 3 июня.

5. Томск, 30 марта // Сибирский вестник. 1902. 30 марта.

6. Сибирские вести // Енисей. 1902. 19 мая.

7. Шиловский М.В. Оформление программы сибирских областников в период революции 1905-1907 гг. // Революционное и общественное движение в Сибири в конце XIX - начале XX вв. / отв. ред. Л.М. Горюшкин. Новосибирск : Сибирское отделение «Наука», 1986. С. 119-132.

8. Шиловский М.В. Сибирское областничество в общественно-политической жизни региона во второй половине ХІХ - первой четверти ХХ в. Новосибирск : Изд-во «Сова», 2008. 270 с.

9. Зиновьев В.П., Харусь О.А. Общественно-политическая жизнь в Томской губернии в 1880 - феврале 1917 г. Хроника. Томск : Изд-во Том. ун-та, 2013. $398 \mathrm{c.}$

10. Сибирская жизнь. 1919. 23 янв.

11. История Сибири с древнейших времен до наших дней. Л. : Наука, 1968. Т. 4. 499 с.

12. Шиловский М.В. Первый премьер-министр Сибири. К 130-летию со дня рождения П.В. Вологодского // Сибирская старина. 1993. № 3. С. $2-4$.

13. Крестьянников Е.А. П.В. Вологодский на пути к адвокатуре: окружение, интересы и деятельность юриста на начальном этапе профессиональной карьеры // Вестник Томского государственного университета. 2017. № 416. С. 113-118.

14. Обзор общественной жизни Сибири // Енисей. 1899. 28 марта.

15. Томская жизнь // Сибирская жизнь. 1907. 21 сент.

16. Сибирский вестник. 1903. 6 апр.

17. Судебные отчеты. Томский окружной суд (От нашего корреспондента). Обвинение священника в клевете // Право. 1902.1 сент.

18. Судебная хроника. Томский окружной суд (От нашего корреспондента) // Енисей. 1901. 13 апр.

19. Судебная хроника (Окончание) // Енисей. 1901. 15 апр.

20. Судебные отчеты. Томский окружной суд (Признание недействительным акта продажи) // Право. 1909.11 окт.

21. Сибирская жизнь. 1917. 23 авг.

22. Политические процессы в России. 1901-1917. Ч. 1. 1901-1905 / общ. ред. Л.И. Гольдмана. М. : Изд-во Всесоюзного общества политкаторжан и ссыльно-поселенцев, 1932. 248 с.

23. Корреспонденции // Красноярец. 1907. 1 мая.

24. Октябрьские дни в Томске. Описание кровавых событий 20-23 октября. Томск : Типолитография М.Н. Кононова, 1905.71 с.

25. В-дский П. Из хроники освободительного движения в Сибири // Сибирские вопросы. Периодический сборник, издаваемый В.П. Сукачевым под редакцией приват-доцента П.М. Головачева. СПб. : Типография Альтушулера. 1906. № 2. С. $242-264$. 
26. История русской адвокатуры. Т. 1. Гессен И.В. Адвокатура, общество и государство (1864-1914) / сост. С.Н. Гаврилов. М. : Юрист, 1997. $376 \mathrm{c}$

27. Красноярец. 1907. 24 окт.

28. К делу о погроме в Томске // Харбин. 1909. 5 сент.

29. Российский государственный исторический архив (далее- РГИА). Ф. 1405. Оп. 542. Д. 245.

30. Государственный архив в г. Тобольске (далее - ГАТ). Ф. 152. Оп. 37. Д. 875

31. РГИА. Ф. 1149. ОП. 12. Д. 63.

32. О суде присяжных. Публичная лекция, читанная профессором Н.Н. Розиным 24 февраля 1901 г. в пользу пострадавших от неурожая Томской губернии. Томск : Типография П.И. Макушина, 1901. 35 с.

33. Крестьянников Е.А. Суд присяжных в дореволюционной Сибири // Отечественная история. 2008. № 4. С. $37-47$.

34. Полное собрание законов Российской империи. Собр. 3 : [в 33 т.]. СПб. : Гос. тип, 1912. Т. 29.

35. Севостьянов В. О присяжных заседателях // Сибирская жизнь. 1909. 14 нояб.

36. ГАТ. Ф. 158. Оп. 2. Д. 264.

37. Вологодский П.К открытию Барнаульского окружного суда // Сибирская жизнь. 1910. 31 окт.

38. Власть в Сибири: XVI - начало XX в. Новосибирск : Изд-во «Сова», 2005. 696 с.

39. Сибирская жизнь. 1909. 17 нояб.

40. Капитал имени присяжных заседателей Томского окружного суда // Красноярский вестник. 1910.17 июля.

41. П. В-ий. Обо всем (Письма с дороги). Письмо I // Сибирский вестник. 1904. 2 июля.

42. Суд присяжных в России: Громкие уголовные процессы 1864-1917 гг. / сост. С.М. Казанцев. Л. : Лениздат, 1991. 512 с.

43. В.Д. Спасович (Некролог) // Вестник права. 1906. № 10. С. 488-491.

44. Томское юридическое общество // Право. 1903. 8 июня.

45. Сибирская жизнь. 1909. 28 авг.

46. Правила адвокатской профессии в России. Опыт систематизации постановлений советов присяжных поверенных по вопросам профессиональной этики / сост. член совета присяжных поверенных округа Московской судебной палаты А.Н. Марков. М. : Типография О.Л. Сомовой, 1913. 430 с.

47. Крестьянников Е.А. П.В. Вологодский и присяжные поверенные в Сибири // Вестник Томского государственного университета. 2017. № 419. С. 152-159.

48. Отчет совета присяжных поверенных округа Омской судебной палаты за второй год. С 18 мая 1912 г. по 18 мая 1913 г. Омск : Иртыш, 1914. $133 \mathrm{c}$

49. Звягин С.П. Профессиональная и общественно-политическая деятельность иркутского присяжного поверенного М.С. Стравинского в годы Первой мировой и Гражданской войн (1914-1919 гг.) // Вестник Кемеровского государственного университета. 2014. № 3 (59). C. $186-193$.

50. Шахерова С.Л., Вишневский В.Г. Стравинский Мечислав Станиславович // Административно-судебная система Восточной Сибири конца XIX - начала XX в. в лицах и документах : Материалы к энциклопедии / сост. В.Г. Вишневский. Иркутск : Издание ОАО «Иркутская областная типография № 1 имени В.М. Посохина», 2004. С. 206-209.

51. Государственный архив Красноярского края. Ф. 42. Оп. 1. Д. 307.

52. Хроника // Забайкальская новь. 1912.8 апр.

53. Арсеньев К.К. Заметки о русской адвокатуре. Обзор деятельности Санкт-Петербургского совета присяжных поверенных за $1866-74$ гг. СПб. : Типография В. Демакова, 1875.512 с.

54. Отчет совета присяжных поверенных округа Омской судебной палаты за 1913 г. Год третий. Омск : Иртыш, 1914.109 с.

55. Отчет совета присяжных поверенных округа Омской судебной палаты за 1914 г. Год четвертый. Омск : Печатное искусство, 1915.152 с.

56. Крестьянников Е.А. Феминизация адвокатуры и законодательство Российской империи // Адвокатская практика. 2015 . № 6. С. 44-49.

57. Albisetti J.C. Portia ante portas: women and the legal profession in Europe, ca. 1870-1925 // Journal of Social History. 2000. No. 4 . P. 825-857.

58. [Из газет] // Сибирская жизнь. 1912. 4 февр.

59. По Сибири // Забайкальская новь. 1912. 21 янв.

60. Корреспонденции // Красноярский вестник. 1912. 18 авг.

61. Государственный архив Омской области. Ф. 190. Оп. 1. Д. 188.

62. Отчет совета присяжных поверенных при Омской судебной палате за первый год. С 18 мая 1911 г. по 18 мая 1912 г. Омск : Печатное искусство, 1913. 63 с.

63. РГИА. Ф. 1405. Оп. 531. Д. 203.

64. Сибирская жизнь. 1917. 20 авг.

65. Сибирская жизнь. 1917. 29 авг.

Статья представлена научной редакцией «История» 18 февраля 2018 г.

THE “LIBERAL PROFESSION" OF PYOTR VOLOGODSKY: ADVOCATE TRAJECTORIES OF THE TOMSK LAWYER

Vestnik Tomskogo gosudarstvennogo universiteta - Tomsk State University Journal, 2018, 433, 78-86.

DOI: $10.17223 / 15617793 / 433 / 10$

Evgeniy A. Krestyannikov, Tyumen State University (Tyumen, Russian Federation). E-mail: krest_e_a@mail.ru

Keywords: Pyotr Vologodsky; Siberia; legal profession; legal proceedings.

The aim of article consists in the study of the route and atmosphere of Pyotr Vologodsky's professional career development, clarification of his attitude to his work, assessment of his contribution to public emancipation and also to advocate corporationism, morals and craft. Using microhistorical specification and comparative methods, the author considers participation of the Tomsk lawyer in judicial sessions as the defender and the prosecutor in court, in the life of the community of attorneys. The author pays attention to features of Vologodsky's compearance. The historical sources involved in the research including periodicals, documents of public organizations and materials of archives, and also papers of historians allow to provide insight into the versatile interests of Vologodsky as advocate, into cases in which he participated, into his professional solvency. It is noted that Vologodsky was a participant in the most considerable Siberian lawsuits at the beginning of the 20th century: the case of the Tomsk pogrom in October, 1905; the judicial hearing, first in the history of Siberia, with the participation of jury members; many political processes. The public procedure of legal proceedings that brought the parties together in argument allowed advocates to disclose their own abilities, and was the tool of pressure upon the power and formations of civil society. The future prime minister proved as the supporter of fair judicial competition who was able to win cases using public and political contradictions. At the same time he was noted in community involvement for the legal profession. He did not let rushes of the moment steal up on him and remained apolitical in the corporate commonwealth. 
In the Omsk Council of Attorneys, he worked to improve its staff taking part in disciplinary proceedings. Thanks to Vologodsky, the council made decisions independent of the government, in particular, the inclusion of the woman in the estate and the establishment of independent institutions of assistants of attorneys. Vologodsky loved his profession. He made use of the experience of the best Russian lawyers for professional self-improvement and by that he improved other attorneys. It is necessary to recognize his lawyer practice very successful. His success in lawsuits, high qualification, creative activity, beneficial effect on social development allowed Vologodsky to win respect and to get famous, which promoted him to the leading roles after the falling of autocracy.

\section{REFERENCES}

1. Kazakova, E.A. (2008) P.V. Vologodskiy: lichnost' i obshchestvenno-politicheskaya deyatel'nost' (1863-1920 gg.) [P.V. Vologodsky: personality and socio-political activity (1863-1920)]. History Cand. Dis. Tomsk.

2. Shilovskiy, M.V. (2010) Tomskiy pogrom 20-22 oktyabrya 1905 g.: khronika, kommentariy, interpretatsiya [The Tomsk pogrom of October 2022, 1905: chronicle, commentary, interpretation]. Tomsk: Tomsk State University.

3. Susanin. (1911) Khronika [The Chronicle]. Susanin. 2 March.

4. Enisey. (1901) Korrespondentsiya "Eniseya" [Correspondence of "Enisey"]. Enisey. 3 June.

5. Sibirskiy vestnik. (1902) Tomsk, 30 marta [Tomsk, 30 March]. Sibirskiy vestnik. 30 March.

6. Enisey. (1901) Sibirskie vesti [Siberian News]. Enisey. 19 May.

7. Shilovskiy, M.V. (1986) Oformlenie programmy sibirskikh oblastnikov v period revolyutsii $1905-1907$ gg. [Registration of the program of Siberian regional workers during the revolution of 1905-1907]. In: Goryushkin, L.M. (ed.) Revolyutsionnoe i obshchestvennoe dvizhenie v Sibiri v kontse XIX-nachale XXvv. [The revolutionary and social movement in Siberia in the late 19th - early 20th centuries]. Novosibirsk: Nauka.

8. Shilovskiy, M.V. (2008) Sibirskoe oblastnichestvo $v$ obshchestvenno-politicheskoy zhizni regiona vo vtoroy polovine XIX-pervoy chetverti XX $v$. [Siberian regionalism in the socio-political life of the region in the second half of the 19th - first quarter of the 20th centuries]. Novosibirsk: Izdvo "Sova".

9. Zinov'ev, V.P. \& Kharus', O.A. (2013) Obshchestvenno-politicheskaya zhizn'v Tomskoy gubernii v 1880 - fevrale 1917 g. Khronika [Social and political life in Tomsk Province in 1880 - February 1917. A chronicle]. Tomsk: Tomsk State University.

10. Sibirskaya zhizn'. (1919) 23 January.

11. Okladnikov, A.P. (ed.) (1986) Istoriya Sibiri s drevneyshikh vremen do nashikh dney [History of Siberia from ancient times to our days]. Vol. 4. Leningrad: Nauka.

12. Shilovskiy, M.V. (1993) Pervyy prem'er-ministr Sibiri. K 130-letiyu so dnya rozhdeniya P.V. Vologodskogo [The first prime minister of Siberia. On the 130th anniversary of the birth of P.V. Vologodsky]. Sibirskaya starina. 3. pp. 2-4.

13. Krest'yannikov, E.A. (2017) P.V. Vologodsky on the way to the legal profession: the environment, interests and activities of the lawyer at the initial stage of his professional career. Vestnik Tomskogo gosudarstvennogo universiteta - Tomsk State University Journal. 416. pp. 113-118. (In Russian). DOI: 10.17223/15617793/416/17

14. Enisey. (1899) Obzor obshchestvennoy zhizni Sibiri [Overview of the social life of Siberia]. Enisey. 28 March.

15. Sibirskaya zhizn'. (1907) Tomskaya zhizn' [Life in Tomsk]. Sibirskaya zhizn'. 21 September.

16. Sibirskiy vestnik. (1903). 6 April.

17. Pravo. (1902) Sudebnye otchety. Tomskiy okruzhnoy sud (Ot nashego korrespondenta). Obvinenie svyashchennika v klevete [Court reports. Tomsk District Court (From our correspondent). The priest accused of slander]. Pravo. 1 September.

18. Enisey. (1901) Sudebnaya khronika. Tomskiy okruzhnoy sud (Ot nashego korrespondenta) [Court chronicle. Tomsk District Court (From our correspondent)]. Enisey. 13 April.

19. Enisey. (1901) Sudebnaya khronika (Okonchanie) [Court chronicle (end)]. Enisey. 15 April.

20. Pravo. (1909) Sudebnye otchety. Tomskiy okruzhnoy sud (Priznanie nedeystvitel'nym akta prodazhi) [Court reports. Tomsk District Court (Sale act recognized invalid)]. Pravo. 11 October.

21. Sibirskaya zhizn'. (1917). 23 August.

22. Gol'dman, I.L. (ed.) (1932) Politicheskie protsessy v Rossii. 1901-1917 [Political processes in Russia. 1901-1917]. Pt. 1. Moscow: Izd-vo Vsesoyuznogo obshchestva politkatorzhan i ssyl'no-poselentsev.

23. Krasnoyarets. (19070 Korrespondentsii [Correspondence]. Krasnoyarets. 1 May.

24. Anon. (1905) Oktyabr'skie dni v Tomske. Opisanie krovavykh sobytiy 20-23 oktyabrya [The October Days in Tomsk. Description of the bloody events of October 20-23]. Tomsk: Tipolitografiya M.N. Kononova.

25. V-dskiy, P. (1906) Iz khroniki osvoboditel'nogo dvizheniya v Sibiri [From the chronicle of the liberation movement in Siberia]. In: Sibirskie voprosy. Is. 2. St. Petersburg: Tipografiya Al'tushulera. pp. 242-264.

26. Gavrilov, S.N. (ed.) (1907) Istoriya russkoy advokatury [History of the Russian Bar Association]. Vol. 1. Moscow: Yurist.

27. Krasnoyarets. (1907) 24 October.

28. Kharbin. (1909) K delu o pogrome v Tomske [On the case of the pogrom in Tomsk]. Kharbin. 5 September.

29. Russian State Historical Archive (RGIA). Fund 1405. List 542. File 245. (In Russian).

30. State Archive of Tobolsk (GAT). Fund 152. List 37. File 875. (In Russian).

31. Russian State Historical Archive (RGIA). Fund 1149. List 12. File 63. (In Russian).

32. Rozin, N.N. (1901) O sude prisyazhnykh. Publichnaya lektsiya, chitannaya professorom N.N. Rozinym 24 fevralya 1901 g. v pol'zu postradavshikh ot neurozhaya Tomskoy gubernii [On the trial of jurors. Public lecture read by Professor N.N. Rosin on February 24, 1901 in favor of the victims of the crop failure of Tomsk Province]. Tomsk: Tipografiya P.I. Makushina.

33. Krest'yannikov, E.A. (2008) Sud prisyazhnykh v dorevolyutsionnoy Sibiri [The jury trial in pre-revolutionary Siberia]. Otechestvennaya istoriya. 4. pp. 37-47.

34. Russian Empire. (1912) Polnoe sobranie zakonov Rossiyskoy imperii. Sobr. 3: [v 33 t.] [Complete collection of laws of the Russian Empire. Collection 3: [in 33 vols]]. Vol. 29. St. Petersburg: Gos. tip.

35. Sevost'yanov, V. (1909) O prisyazhnykh zasedatelyakh [On jury members]. Sibirskaya zhizn'. 14 November.

36. State Archive of Tobolsk (GAT). Fund 158. List 2. File 264. (In Russian).

37. Vologodskiy, P. (1910) K otkrytiyu Barnaul'skogo okruzhnogo suda [On the opening of the Barnaul District Court]. Sibirskaya zhizn'. 31 okt.

38. Akishin, M.O. \& Remnev, A.V. (eds) (2005) Vlast'v Sibiri: XVI - nachalo XX v. [Power in Siberia: 16th - early 20th centuries]. Novosibirsk: Izd-vo "Sova".

39. Sibirskaya zhizn'. (1909). 17 November.

40. Krasnoyarskiy vestnik. (1910) Kapital imeni prisyazhnykh zasedateley Tomskogo okruzhnogo suda [The capital of the name of jury members of the Tomsk District Court]. Krasnoyarskiy vestnik. 17 July.

41. V-iy, P. (1904) Obo vsem (Pis'ma s dorogi). Pis'mo I [About everything (Letters off the road). Letter I]. Sibirskiy vestnik. 2 July.

42. Kazantsev, S.M. (1991) Sud prisyazhnykh v Rossii: Gromkie ugolovnye protsessy $1864-1917$ gg. [The jury in Russia: Big criminal trials of $1864-$ 1917]. Leningrad: Lenizdat.

43. Vestnik prava. (1906) V.D. Spasovich (Nekrolog) [V.D. Spasovich (Obituary)]. Vestnik prava. 10. pp. $488-491$.

44. Pravo. (1903) Tomskoe yuridicheskoe obshchestvo [Tomsk Legal Society]. Pravo. 8 June. 
45. Sibirskaya zhizn'. (1909) 28 August.

46. Markov, A.N. (1913) Pravila advokatskoy professii v Rossii. Opyt sistematizatsii postanovleniy sovetov prisyazhnykh poverennykh po voprosam professional'noy etiki [Rules of the profession of defense lawyer in Russia. Experience in the systematization of decisions of boards of sworn attorneys on professional ethics]. Moscow: Tipografiya O.L. Somovoy.

47. Krest'yannikov, E.A. (2017) P.V. Vologodsky and sworn attorneys in Siberia. Vestnik Tomskogo gosudarstvennogo universiteta - Tomsk State University Journal. 419. pp. 152-159. (In Russian). DOI: 10.17223/15617793/419/20

48. Board of Sworn Attorneys of the District of the Omsk Chamber of Justice. (1914) Otchet soveta prisyazhnykh poverennykh okruga Omskoy sudebnoy palaty za vtoroy god. $S 18$ maya $1912 \mathrm{~g}$. po 18 maya $1913 \mathrm{~g}$. [Report of the Board of Sworn Attorneys of the District of the Omsk Chamber of Justice for the second year. From May 18, 1912 to May 18, 1913]. Omsk: Irtysh.

49. Zvyagin, S.P. (2014) Professional and socio-political activity of Irkutsk attorney M.S. Stravinsky during World War I and the Civil War (19141919). Vestnik Kemerovskogo gosudarstvennogo universiteta - Bulletin of Kemerovo State University. 3 (59). pp. 186-193. (In Russian).

50. Shakherova, S.L. \& Vishnevskiy, V.G. (2004) Stravinskiy Mechislav Stanislavovich [Mechislav Stanislavovich Stravinsky]. In: Vishnevskiy, V.G. (ed.) Administrativno-sudebnaya sistema Vostochnoy Sibiri kontsa XIX-nachala XX v. v litsakh $i$ dokumentakh: Materialy $k$ entsiklopedii [Administrative and judicial system of Eastern Siberia of the late 19th - early 20th centuries in persons and documents: Materials for the encyclopedia]. Irkutsk: Izdanie OAO "Irkutskaya oblastnaya tipografiya № 1 imeni V.M. Posokhina".

51. State Archive of Krasnoyarsk Krai. Fund 42. List 1. File 307. (In Russian).

52. Zabaykal'skaya nov'. (1912) Khronika [The chronicle]. Zabaykal'skaya nov'. 8 April.

53. Arsen'ev, K.K. (1875) Zametki o russkoy advokature. Obzor deyatel'nosti Sankt-Peterburgskogo soveta prisyazhnykh poverennykh za 1866$74 \mathrm{gg}$. [Notes on the Russian Bar Association. Overview of the activities of the St. Petersburg Council of Attorneys for 1866-74]. St. Petersburg: Tipografiya V. Demakova.

54. Board of Sworn Attorneys of the District of the Omsk Chamber of Judges. (1914) Otchet soveta prisyazhnykh poverennykh okruga Omskoy sudebnoy palaty za 1913 g. God tretiy [Report of the Board of Sworn Attorneys of the District of the Omsk Chamber of Justice for 1913. Year Three]. Omsk: Irtysh.

55. Board of Sworn Attorneys of the District of the Omsk Chamber of Judges. (1915) Otchet soveta prisyazhnykh poverennykh okruga Omskoy sudebnoy palaty za $1914 \mathrm{~g}$. God chetvertyy [Report of the Board of Sworn Attorneys of the District of the Omsk Chamber of Justice for 1913. Year Four]. Omsk: Irtysh.

56. Krest'yannikov, E.A. (2015) Feminization of the legal profession and the laws of the Russian Empire. Advokatskaya praktika-Advocate's Practice. 6. pp. 44-49. (In Russian).

57. Albisetti, J.C. (2000) Portia ante portas: women and the legal profession in Europe, ca. 1870-1925. Journal of Social History. 4 . pp. 825-857.

58. Sibirskaya zhizn'. (1912) [Iz gazet] [[From newspapers]]. Sibirskaya zhizn'. 4 February.

59. Zabaykal'skaya nov'. (1912) Po Sibiri [In Siberia]. Zabaykal'skaya nov'. 21 January.

60. Krasnoyarskiy vestnik. (1912) Korrespondentsii [Correspondence]. Krasnoyarskiy vestnik. 18 August.

61. State Archive of Omsk Oblast. Fund 190. List 1. File 188. (In Russian).

62. Board of Sworn Attorneys of the District of the Omsk Chamber of Judges. (1914) Otchet soveta prisyazhnykh poverennykh pri Omskoy sudebnoy palate za pervyy god. $\mathrm{S} 18$ maya $1911 \mathrm{~g}$. po 18 maya $1912 \mathrm{~g}$. [Report of the Board of Sworn Attorneys of the District of the Omsk Chamber of Justice for the first year. From May 18, 1911 to May 18, 1912]. Omsk: Irtysh.

63. Russian State Historical Archive (RGIA). Fund 1405. List 531. File 203. (In Russian).

64. Sibirskaya zhizn'. (1917) 20 August.

65. Sibirskaya zhizn'. (1917) 29 August.

Received: 18 February 2018 